\title{
WILD LIFE RESEARCH IN EAST AND CENTRAL AFRICA
}

\author{
By P. A. Jewell \\ Research Fellow of the Zoological Society of London
}

This visit took place from August to October, 1962, and its aim was threefold : first, to see and observe large African mammals in their natural environment; second, to visit places where research into the ecology and breeding biology of these animals is being carried out and, third, to become familiar with the conditions and requirements for field work in Africa.

In East Africa most time was spent in Uganda, but a brief visit was made to Kenya and from there a single day's journey was made to Seronera in Tanganyika. In Central Africa all the time in the field was spent in Northern Rhodesia, but a long stay in Salisbury afforded an opportunity to meet people in Southern Rhodesia concerned with wild life research and conservation.

\section{UGANDA}

My first base in Uganda was Kampala. Excursions into the surrounding country revealed an unending expanse of shamba cultivation, and the dense population of the whole of south and central Uganda has virtually cleared these areas of game. Indeed, my general impression of Uganda is of a very crowded country in which the Queen Elizabeth Park and Murchison Falls Park, together with their adjacent game reserves, and such fine areas as the Semliki, will soon be the only places in which large mammals survive. This may not apply to the north and east (Karamoja) districts, which I was not able to visit as roads were impassable to an ordinary car, but which I was told are much more wild and primitive. A third national park, the Kidepo, has just been established here.

On 17th August I drove to the Queen Elizabeth Park which borders Lake Edward in West Uganda. I took with me Mr. C. Field, a Cambridge graduate who had just come out to start work at the Nuffield Unit of Tropical Animal Ecology. His particular task will be analysing the stomach contents and food consumption and preferences of the hippopotamus. I stayed at Mweya with Dr. R. M. Laws, the Senior Investigator of NUTAE, and spent ten days joining in his work and seeing the Park.

The hippopotamus is the first subject of intensive study by NUTAE. Hippopotamus have greatly increased in numbers and present a management problem in the Park, and to try to control them 1,000 are being cropped in a year. The project was of particular interest to me as, when in 1957 some alarm was first raised at the damage they were doing, I had expressed willingness to go out and collect material for study had a shooting programme been started. Damage to the habitat is well illustrated by the area round a big hippo wallow north of the Kazinga Channel. The dominant plant is Caparis bush, with occasional Euphorbia trees, and some

The above article is based on a report to the Wellcome Institute of Comparative Physiology. $-E d$. 
ground cover is afforded by coarse and obviously unpalatable grasses, but extensive areas of the ground surface have been grazed bare. Because of the bare ground fire does not sweep through the area, with the result that the bushes do not get retarded periodically and they are spreading.

We carried out a routine count of the hippopotamus, on a long stretch of the lake shore, from the patrol launch. The method was to count schools of hippo as they were approached, and it appeared to be a reliable method as few hippo normally lie completely submerged. The behaviour of hippopotamus varies in this respect with locality, and was quite different, as we discovered, on the Congo side of the lake. Our excursion there was made across the lake to Ishango in the Parc National Albert. The Semliki river forms a wide outlet from the lake and here, as we could see from the high river cliff, hippo lie in large numbers on the bottom of the river, completely submerged. The cliffs form an exceptionally favourable viewpoint for the study of hippopotamus behaviour.

It should be possible to mark hippopotamus individually by ear-tagging, branding or with metal marks, and immobilizing these creatures with drugs has already been successfully carried out at a wallow. The development of these techniques will form an important part of the work.

The hippo are cropped each week, and on 23rd August $I$ joined in the night shoot. The grazing behaviour of hippo, that brings them out of the water and far inland, lends itself to easy shooting. The animals were caught in the landrover headlamps and sometimes a grazing party of two or three hippo would stand dazed together and be felled in one spot. Twenty-two were taken on this night, and early next morning they were allocated to buyers, butchered and carted away for fresh sale. The biologists had to work very fast to retrieve all the tissues they required but the butchers left behind a nicely cleaned lower jaw (to be used for ageing) from every animal.

The hippopotamus meat is sold fresh, but it may be possible to salt and dry it. With this possibility in mind I visited the "Tufmac" fish processing factory. This factory is supplied entirely by fish from Lake George, and judging by the excellence of their product it would be most advantageous to the cropping scheme if they would process hippo meat.

Of the other species in the Park the ubiquitous buffalo is one of the most numerous. Herds of over 100 are frequently encountered and bachelor parties of three or four males are very common. It would be extremely interesting to study their herd structure, social behaviour and breeding biology, and as their range overlaps with that of the hippopotamus it would be most valuable if the two species could be studied in parallel. Mention must be made of the red-coated buffalo because they are such strikingly handsome animals. A small proportion of the Queen Elizabeth Park animals, especially females, have this colouring. But in the Congo a high proportion, including bulls, are red. (A group of these red buffalo would form a very attractive zoo exhibit.) The biggest herds of buffalo were seen near Ishasha at the south end of the Queen Elizabeth Park. Here the habitat is open grassland and it carries great herds of topi and kob. It is an ideal area for study.

On my last day at Mweya I joined in an attempt to immobilize animals 


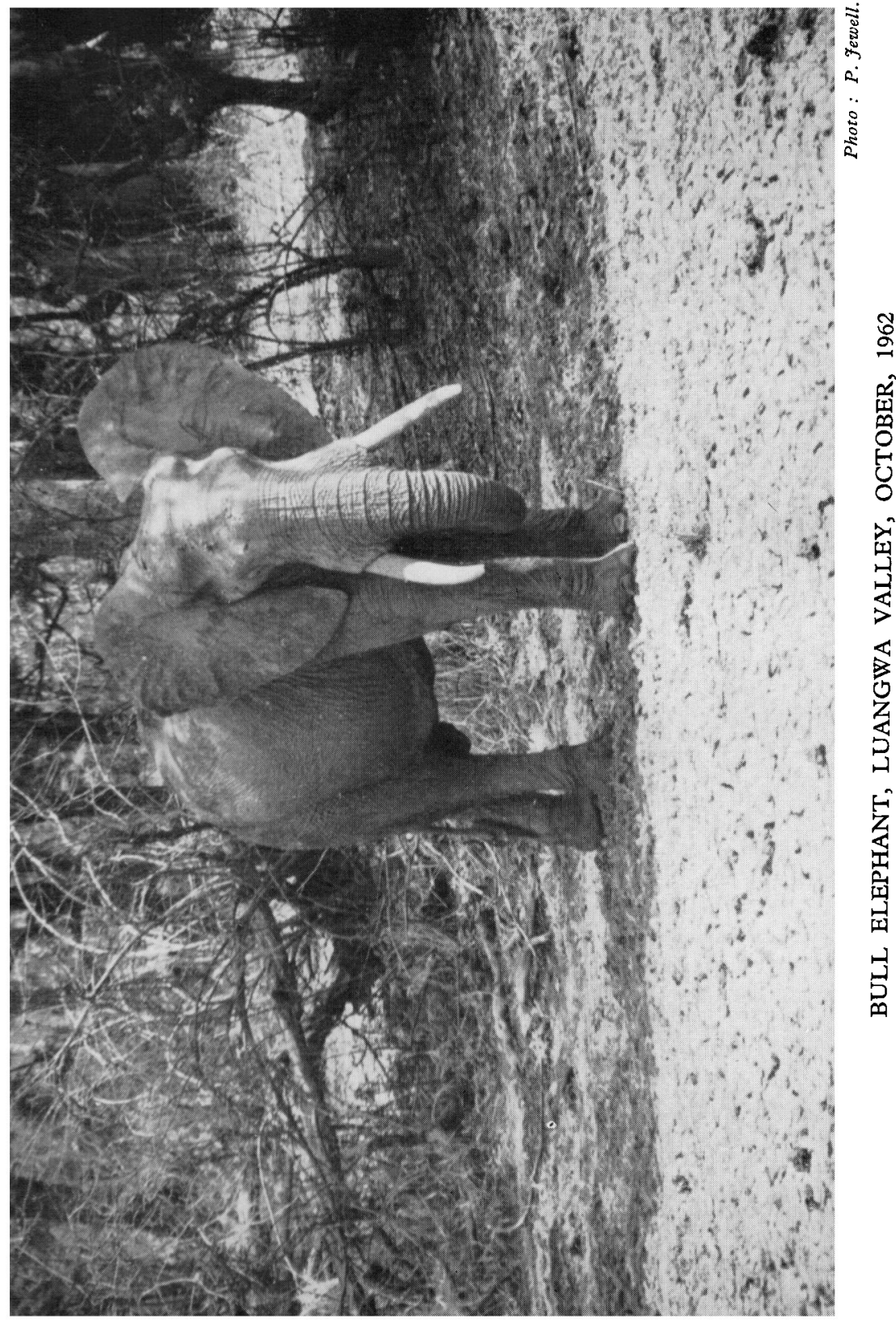




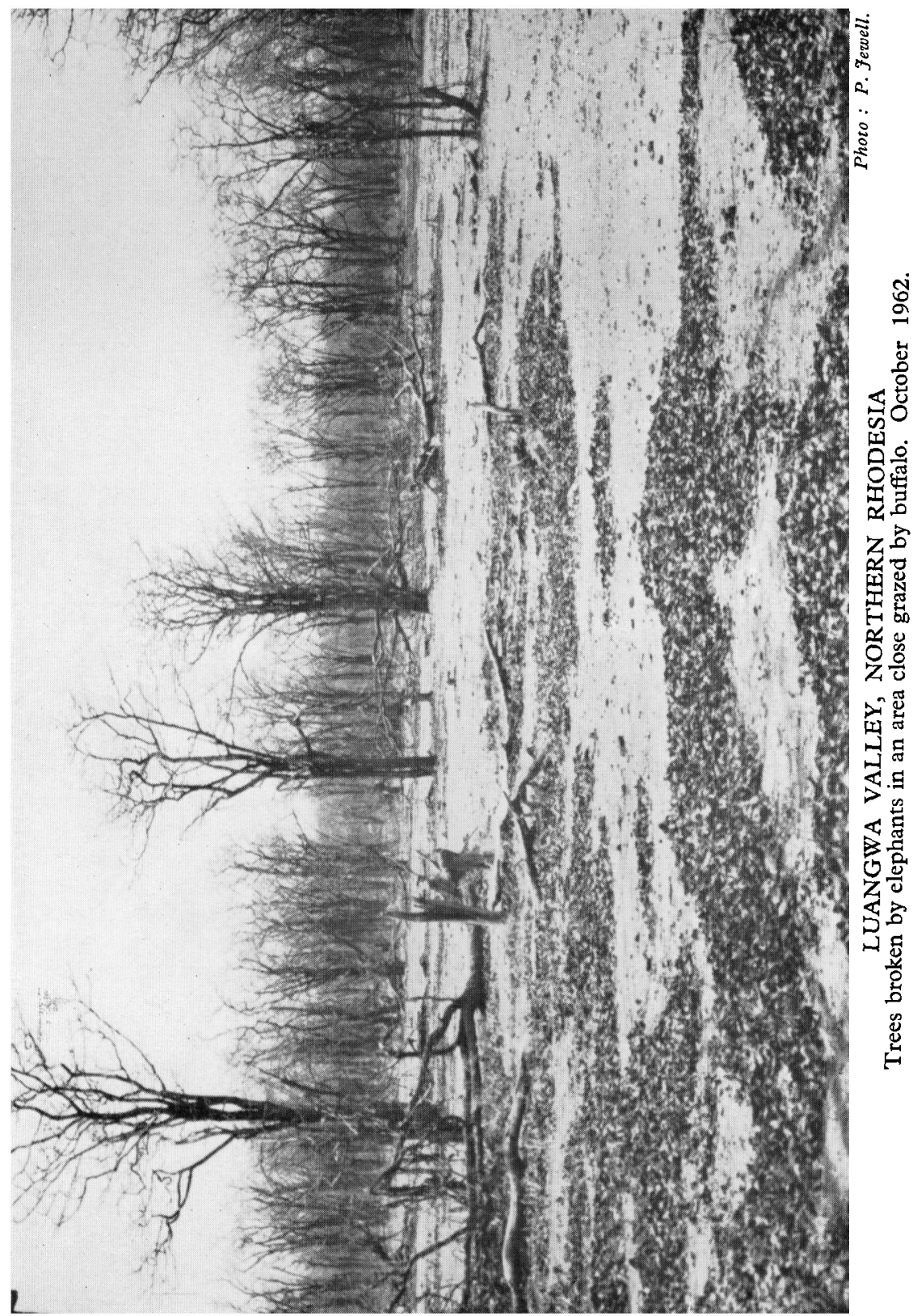


using the drug and projectile syringe technique. Mr. Palmer (of the company which markets the Capchur Gun) was making a day visit and had brought an experimental powder-charged gun, and the Royal Veterinary College student party had also arrived at Mweya and were in camp there. A waterbuck was successfully immobilized, and buffalo were chased and hit, but escaped in the bush. No doubt, however, they could be handled by this method.

On Monday, 27th August, I drove to meet Professor H. Buechner at Kasese and together we journeyed to his camp in the Semliki. This was the most attractive country I saw in Uganda. From the highlands around Fort Portal the approach to the Semliki Plain is down a spectacular steepsided valley, along a precipitous mountain road, to emerge eventually on the plain itself with its tall dry grass, tamarind trees, scattered palms and riparian forests. Buechner's camp was in an ideal place, near the Wanza river, where in the day we were entertained by colobus and vervet monkeys in the nearby canopy, and at night we could hear the voices of elephant, lion and hyaena.

Buechner's study is on the Uganda kob, which shows an exceptionally interesting herd structure and reproductive behaviour. Some $10,000 \mathrm{kob}$ exist on the flats and they breed throughout the year. Mating takes place only on the territorial mating grounds, of which about seventeen are known in the area. These grounds are small, well-grazed, even barren arenas on which, at any given time, some twenty adult male kob maintain contiguous territories. Buechner is studying the movement of males, how long they maintain a territory on the mating ground, the size and structure of herd served by a mating ground, the succession and turnover of males, mating behaviour and the reproductive physiology of the female. We spent a day together in a hide overlooking one of the mating grounds, and witnessed the whole cycle of events. On another day we dissected a number of animals that had been shot. In this species the female implants the embryo invariably in the right horn of the uterus. Buechner's study is timely because the manifestation of the striking territorial behaviour of this species may depend upon there being a large congregation of individuals in a chosen area. Hunting and reduction of numbers could disrupt the pattern. Already the Wildlife Development Corporation have set up a hunting lodge in the area!

I spent five days at Buechner's camp and then on 2nd September went to spend five days with John Savidge, the Warden at Murchison Falls Park. Savidge has recently been made Scientific Officer in the Game Department and is at present making a survey of the new Kidepo Park. At Murchison I saw evidence of too many elephant-in tree destruction and changed habitat-and the management problem they create; and at the other extreme I experienced the difficulties encountered in trying to suppress the activities of crocodile poachers who are leaving too few crocodiles. Also at Murchison I saw black rhinoceros for the first time, but failed to see any of the recently introduced white rhinoceros. Ten of these animals were transferred from the West Nile Reserves and at least six of them have been seen, apparently healthy, in their new habitat. The white rhinoceros were moved because severe poaching had threatened them 
with extinction. Savidge described a visit they had made to the West Nile Reserve when they had quartered the area very thoroughly in a landrover to count the rhinoceros. Some fifty animals were seen but in addition the skeletons of sixty white rhinoceros were encountered. I asked if the skulls had been collected, but they had not. Such a collection, from a single population, would have been of enormous value for study. One piece of information that could have been derived was an indication of the agestructure of the population, and this would have been of immediate interest to those who have to formulate management policies. It was depressing to learn that none were salvaged, though understandable that the small and over-worked staff of the Game Department did not undertake the task. Here was a glaring example of the need for more biologists in the field in Africa.

\section{KenYA}

The visit to Murchison Falls Park ended my tour in Uganda. I returned to Kampala and on 9th September flew to Nairobi in Kenya. I stayed with Dr. A. M. Harthoorn, ${ }^{1}$ but as his teaching term at the Veterinary School was in progress we were not able to go far from Nairobi, but a day spent immobilizing giraffe on a ranch near Nairobi was particularly instructive to me.

At the Game Department I spent time with Major Grimwood and D. R. M. Stewart the biologist. Stewart is preparing an excellent series of distribution maps for game species in Kenya, and is studying the food preferences of game animals. At the time of my visit an aerial count of elephant in Tsavo National Park had just been completed and Major Grimwood was much concerned with the huge total recorded-16,000 elephants. Elephant damage in the Park has been obvious for some time, but their high density may have more serious repercussions. Tsavo is one of the best areas for black rhinoceros but a short while ago there was a heavy mortality among them, some ninety carcasses being observed. The cause of death is not known, but a peculiar skin lesion was recorded amongst the rhinoceros at the time. A disease or parasites could be responsible for the deaths, but there is also the suspicion that high elephant numbers, by damaging the habitat and perhaps competing for food, have created adverse conditions. I enquired whether the skulls had been collected from the carcasses but none had. The rhinoceros appears to be one of the most vulnerable but least studied of the great African mammals.

There was talk of drastically reducing elephant numbers, and of gaining a respite for the deteriorating habitat, by shooting large numbers of elephant and not necessarily attempting to use the carcasses. I suggested that if this were planned then an intensive elephant-marking programme now (Dr. Laws suggests a projectile mark as used on whales) could yield most valuable information about movements and herd structure when shooting allowed recovery of such animals. But it must be admitted that the results of a heavy shooting programme are unpredictable and might bring a train of new problems. For example, unused carcasses might

1 The author of "Translocation as a Means of Preserving Wild Animals," Oryx, VI, 4, April, 1962. 
result in a big increase in the scavenger population, with a subsequent threat to young ungulates. A combined operation of biological research, cropping, and study of means of disposal of meat is clearly required.

The East African Agriculture and Forestry Research Organization at Muguga are extending their work to include fundamental studies of the food requirements, digestive efficiency and productivity of wild ungulates. Dr. W. J. A. Payne and his colleagues have already shown how Afrikander cattle can maintain a positive nitrogen balance on a diet containing as little as 2 per cent protein. This is achieved in the face of very low water intake and appears to involve an efficient re-absorbtion and utilization of urea. It can be expected that wild ungulates have such physiological adaptations developed to a marked degree. The work is being supported jointly by the Universities of Oxford and California and two American biologists have already come to join the organization.

\section{RHODESIA}

On 19th September I flew down to Salisbury in Southern Rhodesia. An exciting two weeks in the game reserves of Northern Rhodesia awaited me, but I should first outline some of the information I gathered from people in Salisbury.

The Zoology Department of the University is preparing to run a course on wild life conservation and has already run a successful trial course of which I was given the synopsis. Two American Fulbright Fellows, Drs. R. Genelly and L. K. Sowls, are advising on the course and are themselves doing some work on mammals. In September, 1963, the Zoological Society of Southern Africa is going to hold a "Symposium on African Mammals" in the Department.

A new study reserve has been created on the south bank of Lake Kariba, and a field laboratory will be established here. It will form an area for basic ecological studies and I understand that Oxford University has an interest in this development.

Southern Rhodesia is one of the territories in which game animals are still systematically slaughtered in an attempt to suppress the tsetse-fly. Three-quarters of a million head of game have been shot here since this policy began; it would be too shaming to count what number of these had been put to any scientific purpose. General indiscriminate shooting of game is no longer carried out but effort is concentrated where a spread of fly creates a local emergency. This state of emergency was declared in the Nagupandi district in June of this year and a slaughter campaign is now in progress. Mr. J. Ford, Assistant Director of the Tsetse and Trypanosomiasis Control Branch, kindly gave me details of what is being done. Six principal species of game-elephant, buffalo, warthog, kudu, bushbuck and bushpig-are being driven from or destroyed in an area of 200 square miles covering the headwaters of the Nagupandi River. Elephant were tackled first-thirty-three were shot and the rest have deserted the area; buffalo too have apparently now moved out. The shooting of other species had just started (at the beginning of November) 
and so far 216 warthog and ten bushpig have been reported killed. The numbers being killed will presumably progressively decline. The whole operation is expected to last twelve months.

\section{NORTHERN RHODESIA}

My final field excursion, between 1st and 19th October, was to Northern Rhodesia, where Mr. F. I. Parnell, the Director of the Game and Fisheries Department, had arranged an itinerary for me. I was to spend one week in the Kafue National Park with Mr. B. L. Mitchell and one week in the Luangwa Valley with Mr. W. F. H. Ansell. The visit was at an opportune time, the end of the dry season being ideal for seeing game and assessing the state of the habitat.

The Kafue National Park is an enormous area, of over 8,000 square miles, most of it woodland or savannah woodland dominated by the Brachystigia-Isobelinia genera of trees. My journey took me from Ngoma in the south up the west bank of the Kafue river to its confluence with the Lufupa, and from there to the most northerly camp at Ntemwa. The southern part is the more open and one evening we watched a herd of 400 buffalo coming to drink at a pool. The animals create and maintain these pools by wallowing, and the wet sites are made further attractive by the persistent growth of the palatable grass Echinochlea. The Kafue river floods extensive areas during the rains so that aquatic grasslands stretch back from either bank, and back from the courses of its tributaries. This is a favoured habitat of puku and reedbuck. In the north the Lufupa river drains the Busanga Plain, a great aquatic grassland area that forms a special habitat of very great attraction. Of the antelopes it carries red lechwe, oribi, hartebeest, wildebeest, puku and reedbuck, but in addition has a spectacular variety of birds including saddle-billed stork, wattled crane and crested crane, pratincole and courser, coucal and many species of plover.

There are rather few elephant in the Park, and no excess of any herbivore ; on the contrary, the density of game may be below optimal and there is a suspicion that some, in particular the hartebeest, are decreasing in numbers. Because the game are not overcrowded and can move freely to choose their habitat, and because there is no need to interfere to control numbers, the Park forms an ideal area for basic biological studies. There is one problem in that it has been suggested that there are too many lions. Observations on kills show that they take first buffalo and next hartebeest as their most frequent prey. Shooting lion, or alternatively shooting vultures (thereby leaving more meat for the lions and thus reducing their depredations) have been mooted as control measures. It would be a great pity if such measures were initiated without a biological study. Not only has a great deal to be learnt about the lion, but there is an urgent need for the study of the numbers and movement of the scavengers, especially the vultures and the hyaena, a study that could not fail to yield important results for game reserve management.

The Luangwa Valley was the most impressive game area of all that I visited. It seemed like Africa's proverbial Lost Valley. It is an exceptionally wild region and in the dry season many species of large mammal 
congregate along the watercourse of the Luangwa itself, or one of its permanently flowing tributaries. Five game reserves lie along the river and the largest extend back some 40 miles to the rift escarpment. Our journey took us through four of the reserves, but we kept to the river road (the only road!) and so did not see other parts of the habitat. In Chilangozi Reserve in the south we stayed at Lusingazi Camp, on the reserve border, and at night elephant could be seen crossing the river to feed outside the reserve. Here this does not create a serious problem as no villages are near, but it does expose the elephant to hunting which in turn makes them more wild in the reserve. Further north, where villages line one of the few permanent watercourses outside the reserves, the problem is acute. The other camps visited were M'fuwe, Big Lagoon, Luambe and Nsefu. At M'fuwe I met Mr. S. A. H. Klasen, who had taken part in the Kariba rescue operations and who had recorded some interesting observations on the use of calcium and magnesium solutions to offset shock in captured animals. I hope I persuaded him he should submit a paper on this to the Proceedings of the Zoological Society. Big Lagoon Camp lived up to its reputation of providing entertainment even for those sitting in the dining shelter. From here we witnessed a 10 to $12 \mathrm{ft}$. crocodile catch and crunch a $4 \mathrm{ft}$. crocodile and then slowly swallow it whole.

Everywhere there was an abundance and variety of game; black rhinoceros were seen on five occasions, greater kudu were common, giraffe, eland and oribi were seen in small numbers, whilst impala, puku and waterbuck were excessively abundant. When we drove into Nsefu Reserve we counted all the game to be seen within 200 yards on either side of the track. Over a route of 18 miles, 182 head were counted, but it was in the heat of the day between 13.00 and 14.45 hours. We went out again before dusk and on a 2 mile run only, on the Chapera loop, past a lagoon, we counted 158 head. But the species that must be specially mentioned, because of the problems they present, are elephant and buffalo.

Elephant were encountered very frequently; we saw one party of fourteen bulls and many smaller groups of bulls. Herds of females were even more common, always with a few tiny youngsters, and it was evident that many females were accompanied by two or even three of their calves, each separated by a few years in age. Clearly elephant are not only numerous but are breeding rapidly and presumably increasing. That this is true is witnessed by the signs of damage to the habitat, or perhaps to avoid pre-judging the effect, one should say " use of" the habitat. Especially in the northern reserves, in the Mopane woodlands, the proportion of broken and prostrate trees is high, and everywhere young trees are coppiced at a height of 8 feet.

Using the same ground are large congregations of buffalo. The largest herd I counted numbered 450 , but herds of up to 1,000 are often seen. They are reported to have increased greatly in recent years and it is questionable how long the habitat can support these numbers. The herds which I saw appeared to be still finding herbage to graze from the dry grassland, but in addition they were browsing new growth from bushes. Much of the ground was bare and dusty. To what extent these buffalo are causing the habitat to deteriorate has not yet been assessed; as far as 
the animals are concerned, however, I would grade them in fair to good condition. Indeed the buffalo, at least the bachelor groups of old males, looked in better condition than those I had seen in the Queen Elizabeth Park. But their age composition may be different; in the Luangwa predation by lions is heavy, in the Queen Elizabeth Park light.

The Game Department have taken the first steps to cope with the large numbers of elephant and are running a pilot cropping scheme. I saw two elephant being cut up in the bush where they had been shot, and later the meat being shredded and roughly smoked. The whole process was carried out very efficiently. The skeleton and the hide, except ears and feet, were left behind. It struck me that finding an effective use for the hide would improve the economy of the operation (and this applies equally to cropping hippopotamus). The market for elephant-foot umbrella stands must be limited, and that for sjamboks is presumably diminishing. As for the dried meat, it appears that it will keep for long periods in a tobacco barn, and such a structure is being built specifically for this purpose. The pilot scheme is evidently a success, and if the necessary backing is forthcoming it is intended to take some hundreds of elephant and 500 to 1,000 buffalo in a season.

The opportunities for study here are immense. The prodigious amount of material that will be available for collection is only one aspect of the biological richness of the area. The Luangwa Valley would form one of the finest areas for study of the whole complex ecology of African game animals.

\section{Conclusions}

The conclusions can conveniently be considered under four headings.

\section{Potential for Study.}

My primary interest in the game animals was to see what opportunities existed for the study of their breeding biology, particularly in situations where specimens could be taken for the study of tissues. But I must record how great the potential is for the study of almost any aspect of the life of mammals, and of almost every species. The large mammals most urgently need attention because of the management problems they present, but equally the small mammals virtually wait for the study of their ecology to begin.

I should mention four particular aspects of the situation that were impressed upon me by what I saw :-

(a) In the reserves where a variety of large mammals persists the interaction of the animals with their habitat appeared to be on a prodigious scale (contrasted, as it was for me, with the effects of Britain's denuded fauna). The species using the same habitat were impressive by their variety and number, not to mention their conspicuous size. I felt that the organized and intensive study of this dynamic biotope could lead to a rich reward in terms of a new understanding of the factors controlling plant and animal communities, of the population dynamics and breeding success of the mammals and indeed of the evolution of the species themselves.

(b) On the particular subject of mammalian reproduction it was evident 
that any study must have as a background a knowledge of the population status of every species concerned. Where numbers wax and wane, and such cycles may have very long periodicities in terms of tens of years, any study of fertility, duration of breeding season, litter size and all other factors contributing to breeding success must be assessed in relation to the phase of population growth or decline in which the species stands at the time of study.

(c) I was impressed by the potential of information to be gained from a study of animal behaviour. It was fascinating to watch the way in which an elephant applied his trunk and tusks to any task of manipulation. The elephant's versatility, and the longevity of the individual that allows such a variety of experience, must render him peculiarly able to cope with a changing and difficult environment. Again, to watch a troop of baboons was a revelation in animal behaviour. Their movements were a series of complex interactions with their immediate environment, a sequence of food gathering, searching, playing, social contacts and of overcoming the obstacles that they encountered.

Studies of the behaviour of species threatened with extinction, or with disruption of their normal way of life, should have the highest priority.

(d) Finally, one must take note of the ubiquity of man. The presentday settlement of people sets the limit to where animals may roam, and in many countries the imposed restriction to animal movement is severe. But even where people are not settled there is abundant evidence of their past activities. All populations of large mammals have been in some way affected by man, and it would be rash to suppose that the abundance of some species, equally with the scarcity of others, is not the direct or indirect outcome of man's activities. Change in the abundance of game over the last seventy years is remembered by many old men, and here the anthropologist could obtain information that would materially aid our understanding of the African scene. Similarly archaeology, from a study of excavated animal remains, can contribute to our knowledge of the past status of the game. It is the animals, their habitat and man that have to be understood.

\section{Species that Need to be Studied with Urgency.}

(a) The Elephant.-There are many special reasons for carrying out an intensive study of the elephant : its enormously wide range, its ability to adapt itself to a changed habitat, its versatility of behaviour and the fact that elephants of one sort or another have been an important element of the environment in which man has evolved, all make it of special interest. Moreover, the interaction of the elephant with other species is extensive. The elephant can open up a habitat, make water available for other species, or conversely may compete with them (as possibly in the case of the black rhinoceros). The problem of too many elephant already faces us, and there are now few reserves where it does not exist. The prospect of having to slaughter thousands of elephants in the next few years is an imminent one. The creation of an Elephant Research Unit in Africa is long overdue. In addition to the ecological work that such a unit would carry out, and 
the material that it would collect, it would form a base for visiting biologists who could carry out special investigations.

American scientists, in particular Dr. Buss and his colleagues, and many members of game department staffs are doing important work but the scale of the effort is in no way commensurate with the importance of the species.

(b) The Rhinoceros.- The urgency here resides in the scarcity of the animal and the danger of its extinction. One opportunity after another to study the rhinoceros has been missed. The white rhinoceros is receiving some attention in South Africa, but a zoologist is needed in East Africa to start work at once on the black rhinoceros.

(c) The Buffalo.-Like the elephant, buffalo are apparently too numerous in many places. Great numbers have built up in restricted areas in Northern Rhodesia and the habitat is being severely damaged. It seems probable that something in the situation must soon set a limit to this increase and that starvation or disease will cause a sudden population crash.

To meet such events as a crash among buffalo populations or sudden mortality in a rhinoceros population it would be most valuable if a biologist and pathologist could form a stand-by team that would go to the locality of trouble at very short notice.

\section{Opportunities from Tsetse Control and Game Cropping.}

The opportunity to collect material from Tsetse Control slaughter operations is not new. It still exists, however, despite the dubious value of such operations. A new opportunity to collect material is now emerging in the form of cropping schemes. Where regular numbers of a species are being shot at intervals throughout the year, circumstances are ideal for collecting tissues for the study of reproductive cycles. There is some discussion about establishing a "cropping" reserve at Lochinvar Ranch in Northern Rhodesia for proper scientific study, which would form an ideal centre. Meantime there are many places, some of which I have indicated in my report, where zoologists could go to collect material.

\section{Problems Raised by Cropping.}

For cropping to be successful, unlike slaughter for tsetse control, information is urgently needed on the population structure and breeding success of the species involved. Many secondary problems also need study, for example the scavenger populations and the effect on them of cropping schemes. Moreover, there are many attendant difficulties in marketing and using all the animal products from cropping. Scientists in Britain could possibly assist here by arranging for various investigations to be conducted in laboratories in Britain. For example, there are several problems that leather research scientists might tackle, including the processing and use of hippopotamus and elephant hide.

\section{The Role of the Zoological Society of London.}

With the new research potential that has been placed under the control of the Zoological Society of London in its Wellcome Institute of Comparative Physiology and its Nuffield Institute of Comparative Medicine there 
is opportunity to consider ways in which the Society can encourage and contribute to research on large mammals in Africa. Studies on breeding biology, comparative pathology and parasitology have a central bearing on African problems, and it would be particularly appropriate if species that have so long formed the major attraction in the Society's collections could have their management in the wild improved by new knowledge emerging from the Society's research institutes.

There is, moreover, an immediate need for an office that will collate information about game research in Africa, and pass on information about new game-cropping schemes and other projects. It is clear that zoologists themselves have an active part to play in such developments. 